\title{
DERECHO DE EXCEPCIÓN Y GARANTÍA DE LOS DERECHOS EN TIEMPOS DE PANDEMIA
}

\section{RULES OF EXCEPTION AND GUARANTEE OF RIGHTS IN TIMES OF PANDEMIC}

\author{
Marc Carrillo López \\ Universidad Pompeu Fabra
}

Cómo citar / Nola aipatu: Carrillo López, M. (2020). Derecho de excepción y garantía de los derechos en tiempos de pandemia. Legebiltzarreko Aldizkaria - LEGAL - Revista del Parlamento Vasco, (1): 60-93. https://doi.org/10.47984/legal.2020.003

\section{RESUMEN}

La pandemia de la COVID-I9 ha supuesto un reto para el Estado de derecho. La aplicación del Derecho de excepción regulado en la Constitución ha introducido restricciones a los derechos fundamentales a fin de proteger la salud de los ciudadanos. En este estudio se examinan el alcance y los límites del estado de alarma en España, como una de las tres modalidades de Derecho de excepción previstas en la Constitución y la Ley Orgánica 4/198I, que permite afrontar el reto de la pandemia sin que sea necesaria la suspensión de derechos fundamentales. Desde esta perspectiva se analiza el impacto de las medidas de excepción adoptadas por el Gobierno sobre el ejercicio de algunos derechos fundamentales y la respuesta judicial a los recursos presentados por los ciudadanos, en especial respecto a la libertad de circulación y el derecho de manifestación, además de la libertad de expresión especialmente a través de las redes sociales, y la garantía del derecho de habeas data. En todos estos casos se examina la aplicación del test de proporcionalidad para evaluar el ejercicio y los límites del poder público en la aplicación de las medidas destinadas a garantizar la sanidad pública y su incidencia sobre estos derechos fundamentales.

\section{PALABRAS CLAVE}

Derecho de excepción, estado de alarma, derechos fundamentales, libertad de circulación, derecho de reunión y manifestación, habeas data, libertad de expresión, sanidad. 


\section{ABSTRACT}

The COVID-I9 pandemic has been a challenge for the rule of law. The application of the rule of exception regulated in the Constitution has introduced restrictions on fundamental rights in order to protect the health of citizens. This study examines the scope and limits of the state of alarm in Spain, as one of the three forms of the rule of exception provided for in the Constitution and Organic Law 4/198I, which allows facing the challenge of the pandemic without the suspension of fundamental rights being necessary. From this perspective, the impact of the emergency measures adopted by the Government on the exercise of some fundamental rights and the judicial response to the appeals presented by citizens is analyzed, especially with respect to freedom of movement and the right to demonstrate, in addition of freedom of expression especially through social networks, and the guarantee of the right to habeas data. In all these cases, the application of the proportionality test is examined to assess the exercise and limits of public power in the application of the measures designed to guarantee public health and its impact on these fundamental rights.

\section{KEYWORDS}

Rule of exception, state of alarm, fundamental right, freedom of movement, right to meet and demonstrate, habeas data, freedom of expression, health.

\section{LABURPENA}

COVID-Igaren pandemia erronka izan da Zuzenbide Estatuarentzat. Konstituzioan araututako salbuespen-eskubidearen aplikazioak oinarrizko eskubideei murrizketak ezarri dizkie, herritarren osasuna babesteko. Azterlan honetan, alarma-egoerak Espainian duen irismena eta mugak aztertzen dira, Konstituzioan eta 4/198r Lege Organikoan aurreikusitako salbuespen-zuzenbidearen hiru modalitateetako bat den aldetik, pandemiaren erronkari aurre egitea ahalbidetzen baitu, oinarrizko eskubideak etetea beharrezkoa izan gabe. Ikuspegi horretatik aztertzen da Gobernuak hartutako salbuespen-neurriek zer eragin duten oinarrizko eskubide batzuen erabileran eta herritarrek aurkeztutako errekurtsoei emandako erantzun judizialean, bereziki zirkulazio-askatasunari eta manifestatzeko eskubideari dagokienez, bai eta adierazpen-askatasunari dagokionez ere, bereziki sare sozialen eta habeas data eskubidearen bermearen bidez. Kasu horietan guztietan, proportzionaltasun-testaren aplikazioa aztertzen da, osasun publikoa bermatzeko neurrien aplikazioan botere publikoak duen erabilera eta mugak ebaluatzeko, bai eta oinarrizko eskubide horietan duen eragina ebaluatzeko ere.

\section{GAKO-HITZAK}

Salbuespen-eskubidea, alarma-egoera, oinarrizko eskubideak, zirkulazio-askatasuna, biltzeko eta manifestatzeko eskubidea, habeas data, adierazpen-askatasuna, osasuna.

\section{SUMARIO}

I. EL ESTADO DE ALARMA COMO DERECHO DE EXCEPCIÓN EN LA CRISIS SANITARIA. 1. Las medidas de excepción en la Unión Europea. 2. El estado de alarma en el ordenamiento jurídico español y el debate sobre su aplicación tras el Real Decreto 463/2020, de 14 de marzo, por el que se declara el estado de alarma para la gestión de la situación de crisis sanitaria ocasionada por el COVID-19. 3. La coerción estatal ex art. 155 y el estado de alarma ex arts. 55.1 CE y 116.2 CE. 4. Limitación y suspensión de derechos: ¿estado de alarma o estado de excepción?

II. LA LIBERTAD DE CIRCULACIÓN Y EL DERECHO DE REUNIÓN Y MANIFESTACIÓN.

III. EL DERECHO A LA PROTECCIÓN DE LOS DATOS PERSONALES.

IV. LAS REDES SOCIALES COMO SOPORTE DE LA LIBERTAD DE EXPRESIÓN Y DEL DERECHO A COMUNICAR Y RECIBIR INFORMACIÓN. BIBLIOGRAFÍA. 
La pandemia generada por la COVID-19 ha supuesto un reto para los Estados democráticos: ante una situación de excepcionalidad sanitaria a la que ineludiblemente había que hacer frente con premura para garantizar el objetivo prioritario de la salud colectiva y el interés general de la población, ¿cuál había de ser la respuesta desde el Derecho de las instituciones públicas?; ¿los institutos constitucionales vigentes han sido suficientes para abordar la situación, sin mengua de los fundamentos que constituyen las señas de identidad del Estado de derecho?

Porque, en efecto, uno de los riesgos que puede comportar el recurso a las medidas de excepción es que, en el camino que conduce a su aplicación, desarrollo y posterior levantamiento, puedan resultar malparados algunos de los pilares del Estado de derecho, como la división de poderes, y las garantías de los derechos y libertades. El reto al que el Estado democrático se enfrenta cuando se ve en la tesitura de acudir a medidas de excepción lo expresó de forma lúcida el profesor Pérez Serrano (1984: 418), cuando, al tratar de forma general la suspensión de garantías afirmaba que “... es una situación jurídica excepcional, porque con arreglo a Derecho se entra en ella, con arreglo a Derecho se actúa durante ella y con arreglo a Derecho se liquidan sus consecuencias después de ella ...", subrayando de esta manera que la aplicación de las instituciones jurídicas de excepción de preservar, entre otros deberes, el cumplimiento de los principios de legalidad y de seguridad jurídica, frente a la tentación de operar por la vía de hecho a la que una emergencia puede incitar a caer a los responsables públicos. Por ello -añadía- la situación de excepción no exime de la exigencia de “... responsabilidad a los órganos que se hubiesen extralimitado". En consecuencia, la atenuación o la suspensión de garantías constituye “... una fórmula de Derecho, excepcional, extraordinaria, pero que en ningún momento pierde la nota jurídica, siquiera la inevitable espera de libertad discrecional que al Poder público confiere y reconoce pueda en la práctica dar pie a manifestaciones jurídicamente enjuiciables..." (Pérez Serrano, 1984: 418).

En las páginas que siguen se examinarán algunos aspectos de relevancia jurídica relativos a la situación creada por la pandemia. En especial, el marco constitucional español del estado de alarma, en tanto que modalidad específica de Derecho de excepción previsto en la Constitución (art. 116.2 CE), como soporte jurídico a las medidas tomadas, y la incidencia que su aplicación ha tenido sobre el ejercicio y la garantía de algunos derechos fundamentales como la libertad de circulación y desplazamiento (art. $19 \mathrm{CE}$ ), el derecho de reunión y manifestación (art. $21 \mathrm{CE}$ ); el derecho a la protección de los datos personales o habeas data (art. 18.4 CE), o la libertad de expresión y el derecho a la información. En este elenco, ciertamente, no se agotan las cuestiones que han suscitado interés en el debate jurídico, como es el caso, entre otros, del control parlamentario de la acción del Gobierno durante la situación excepcional o los problemas de orden competencial surgidos tras la declaración del estado de alarma y que merecen una atención específica; por ejemplo, la gestión de las 
medidas de aplicación tomadas en el marco de una estructura de Estado compuesto, como es el caso español, que requerirían un examen específico ${ }^{1}$.

\section{EL ESTADO DE ALARMA COMO DERECHO DE EXCEPCIÓN EN LA CRISIS SANITARIA}

\section{LAS MEDIDAS DE EXCEPCIÓN EN LA UNIÓN EUROPEA}

El precedente de la situación creada en Italia en los meses de febrero y marzo de 2020 por la pandemia del coronavirus incidió en las medidas de excepción adoptadas en España en la segunda quincena de marzo. Pero a diferencia del país transalpino, la Constitución de 1978 contempla de forma precisa la regulación de diversas modalidades del llamado Derecho de excepción (arts. 55.1 y 116.2), desarrolladas en la Ley Orgánica 4/1981, de 1 de junio, reguladora de los estados de alarma, excepción y sitio (en adelante, Ley Orgánica 4/1981), cuyo artículo 4.b) prevé que el Gobierno puede acordar el establecimiento del estado de alarma en casos de "crisis sanitarias, tales como epidemias y situaciones de contaminación graves”. De acuerdo con esta cobertura constitucional y legal, se adoptaron las medidas de emergencia para afrontar la grave crisis sanitaria que se concretaron en el Real Decreto 463/2020, de 14 de marzo, por el que se declara el estado de alarma para la gestión de la situación de crisis sanitaria ocasionada por el COVID-192. Unas medidas que estuvieron vigentes hasta finales de junio mediante seis prórrogas solicitadas por el Gobierno y acordadas por el Congreso.

Hasta ahora, el estado de alarma se ha aplicado en España en una única ocasión. Fue una decisión adoptada por el Gobierno de Rodríguez Zapatero en diciembre de 2010, para hacer frente al cierre del espacio aéreo ocasionado por la huelga encubierta de los controladores aéreos. La finalidad perseguida entonces fue restablecer el servicio público esencial del transporte aéreo ${ }^{3}$.

En el marco de la Unión Europea, el artículo 168.5 del Tratado de Funcionamiento de la Unión Europea (Tratado de Lisboa) atribuye al Parlamento Europeo y al Consejo de Ministros de Sanidad la adopción de "medidas de fomento destinadas a proteger y mejorar la salud humana y, en particular, a luchar contra las pandemias fronterizas...”. Por parte de algunos Estados miembros de la Unión, las medidas de excepción han sido diversas.

1 Para una primera aproximación al tema: Velasco Caballero (2020).

2 https://www.boe.es/eli/es/rd/2020/03/14/463

3 En la fase de corrección de las galeradas de este artículo, como consecuencia de la acentuación de los contagios por la COVID-19 registrada después del verano, el Gobierno ha resuelto aprobar el Real Decreto 926/2020, de 25 de octubre, por el que se declara el estado de alarma, con una duración de 6 meses. 
A lo largo del mes de marzo, en Italia, el gobierno del premier Giuseppe Conte adoptó medidas restrictivas sobre la población a través del uso de la legislación de urgencia. A falta de una previsión específica sobre el derecho de excepción en la Constitución de 1948, el ejecutivo italiano recurrió al instituto jurídico del decreto ley. En aquel momento fueron dos: el primero, fue el Decreto Ley número 6, de 23 de febrero de 2020, convalidado por el Senado con algunas modificaciones como consecuencia de la abrogación contenida en el nuevo Decreto Ley número 19, relativa al artículo 2, que puso remedio a un evidente defecto de indeterminación que introducía una atribución

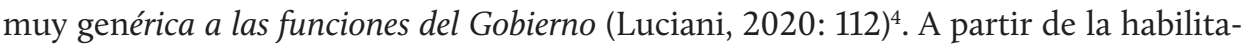
ción constitucional y del citado decreto ley modificado, han sido los decretos del Presidente del Consejo de Ministros la principal fuente normativa para hacer frente a la emergencia.

El impacto de las medidas relacionadas con la actividad cotidiana de los ciudadanos fue especialmente severo, pues incidían sobre el ejercicio cotidiano de alguno de sus derechos fundamentales. No obstante, la cobertura constitucional de esas medidas no fue cuestionada por la mayoría de la doctrina italiana de Derecho público. En una entrevista concedida el 8 de marzo de 2020 al diario Repubblica, el reputado constitucionalista Gaetano Azzariti, catedrático de La Sapienza de Roma, declaraba que, en efecto, las medidas gubernamentales gozaban de plena validez constitucional. Entre sus argumentos destacaba que la Constitución italiana prevé que la libertad de circulación pueda ser limitada por motivos de sanidad y seguridad (art. 16, párrafo primero); que la libertad de reunión puede ser impedida por fundados motivos de seguridad o de salud pública (art. 17, párrafo tercero); y, asimismo, añadía que el derecho a la salud no solo es un derecho fundamental de los ciudadanos sino también de interés para la colectividad (Milella, 2020).

En otros Estados de la UE, las medidas tomadas para afrontar los efectos de la pandemia se han ubicado también en las diversas modalidades constitucionales o legales de los institutos jurídicos de urgencia. Así, en Francia, sin necesidad de acudir al artículo 16 de la Constitución, que atribuye amplios poderes al presidente de la República, se recurrió a un simple decreto del mismo, de 16 de marzo de 2020, invocando el Código de Salud, que impuso medidas de confinamiento de personas en sus domicilios, con algunas excepciones previstas específicamente en dicha disposición.

En la República Federal de Alemania, la libertad de movimiento y de residencia en la totalidad del territorio federal solo puede ser restringida, entre otras causas, "para combatir peligros de epidemia, catástrofe natural o accidente especialmente grave ..." (art. 11.2). De acuerdo con esta habilitación constitucional, la Ley Federal de Protección

4 El tenor del precepto derogado era el siguiente: "Le autorità competenti, con la modalità previste dall’articolo 3 , commi 122 possono addotare ulteriore misure di contenimento e gestione dell'emergenza, al fine de prevenire la diffusione dell'epidemia da COVID-19 anche fuori del casi di cui all'articolo 1 , comma 1 ". 
contra Infecciones, de 20 de julio de 2000 , los länder han podido adoptar mediante decreto medidas restrictivas o limitativas entre las cuales se encuentra el confinamiento (De la Quadra Salcedo III, 2020: 9).

En Bélgica, a pesar de la intransigencia de la Constitución de 1831, en cuyo artículo 187 en principio quedó proscrita la suspensión total o parcial de la Constitución, su historia constitucional más reciente pone de relieve que la atribución al Gobierno de poderes especiales no ha sido excluida. El fundamento constitucional para ello se encuentra en el artículo 105 de la Constitución, donde se establece que el Rey no dispone de otros poderes que los que le atribuye aquella, y las leyes especiales adoptadas de acuerdo con la norma suprema.

Según el parecer emitido el 31 de mayo de 1996 por la Sección Legislativa del Consejo de Estado, para que estos poderes sean compatibles con el artículo 105 es preciso que cumplan las condiciones siguientes: 1) que concurran circunstancias excepcionales o de crisis; 2) que, en función de aquellas, los poderes especiales sean atribuidos por un periodo limitado; 3 ) sus objetivos y las medidas a adoptar han de ser determinados con precisión; 4) la adopción de poderes especiales ha de respetar tanto las normas supranacionales e internacionales como también el sistema constitucional de distribución de competencias entre la colectividad federal y las colectividades federadas.

De acuerdo con ello, en el ámbito federal, el 27 de marzo de 2020 el Parlamento adoptó dos leyes de poderes especiales que habilitaban al Rey "à prendre des mesures de lutte contre la propagation du coronavirus Covid-19” (Verdussen, 2020). Entre las medidas adoptas en la segunda de estas leyes estaban previstas algunas de carácter general destinadas a combatir la propagación del virus en el seno de la población, así como la salud pública y el orden público; la garantía de la capacidad logística para el aprovisionamiento, el apoyo directo o indirecto a la economía en los sectores más afectados, etc. ${ }^{5}$

En el ámbito federado, las regiones y comunidades belgas, con algunos días de antelación -a partir del 17 de marzo de 2020- algunas de ellas adoptaron medidas especiales: fue el caso de la región de Valonia, la Comunidad francesa, la región de Bruselas-capital, y la Comunidad germana. Por el contrario, inicialmente, la región y las comunidades flamencas decidieron no adoptar medidas del mismo tenor, bajo el argumento de que las reuniones del Parlamento seguían siendo posibles y, por tanto, los principios democráticos serían mejor respetados manteniendo el régimen ordinario

5 " $1{ }^{\circ}$ combattre la propagation ultérieure du coronavirus COVID-19 au sein de la population, y compris le maintien de la santé publique et de l'ordre public ;

$2^{\circ}$ garantir la capacité logistique et d’accueil nécessaire, y compris la sécurité d’approvisionnement, ou en prévoir dauantage ;

$3^{\circ}$ apporter un soutien direct ou indirect, ou prendre des mesures protectrices, pour les secteurs financiers, les secteurs économiques, le secteur marchand et non marchand, les entreprises et les ménages, qui sont touchés, en vue de limiter les conséquences de la pandémie ;

$4^{\circ}$ garantir la continuité de l'économie, la stabilité financière du pays et le fonctionnement du marché, ainsi que protéger le consommateur ; etc". Tomado de: https://dice.uniu-amu.fr/fr/dice/dice/recherche/axe-3-democratie-etat-droit-droits-fondamentaux 
de poderes entre el Parlamento y el Gobierno. No obstante, pocos días después, mediante el Decreto del 20 de marzo el Gobierno de Flandes fue habilitado para adoptar nuevas medidas, aunque formalmente no se trató de un decreto de poderes especiales (Verdussen, 2020).

En Suiza, las primeras medidas a nivel federal fueron adoptadas el 28 de febrero de 2020 por el Consejo Federal, que aprobó una ordenanza destinada a luchar contra la COVID-19. Incluyó cinco disposiciones por las que, entre otras medidas, quedaba prohibida la organización de manifestaciones públicas o privadas de más de mil personas; si se trataba de un número inferior los organizadores, en colaboración con la autoridad cantonal competente, debían evaluar los riesgos para determinar si la manifestación podía llevarse a cabo. A esta ordenanza le siguió otra posterior, de 13 de marzo, que incluyó doce disposiciones de contenido más amplio que introducían restricciones sobre otros derechos de libertad e incluso de participación especialmente relevantes en el sistema constitucional suizo, como es el caso del referéndum (Hottelier, 2020). Esta segunda ordenanza estaba dirigida a regular las medidas destinadas a la población en general, las organizaciones, las instituciones y los cantones, al objeto de disminuir el riesgo de transmisión del virus y luchar contra su difusión. Entre estas medidas estaban previstas: el mantenimiento de la capacidad sanitaria, la restricción del tráfico fronterizo, la prohibición de actividades presenciales en las escuelas, etc. Asimismo, pocos días después, el 20 de marzo, el consejo decidió suspender el plazo aplicable a las iniciativas populares federales relativas a las solicitudes de referéndum a celebrar en el ámbito federal.

El fundamento constitucional de estas medidas especiales se encuentra en el artículo 185.3 de la Constitución de 18 de abril de 1999, que habilita al Consejo Federal para decretar ordenanzas de carácter temporal al objeto de afrontar situaciones que amenacen gravemente el orden público, la seguridad exterior o interior. Y también en el artículo 173.1, que permite a la Asamblea Federal actuar en situaciones de urgencia de manera paralela al Consejo Federal y adoptar ordenanzas de contenido normativo. El elemento común de las ordenanzas gubernamentales y legislativas es que no pueden ser sometidas a referéndum. Sectorialmente, la habilitación legal se encuentra en la Ley de epidemias, de 28 de septiembre de 2012. Asimismo, el régimen de urgencia también está previsto en las constituciones de diversos cantones.

Cabe subrayar que, en Suiza, tanto la noción como la declaración del régimen de urgencia y las medidas que incluye escapan a todo control jurisdiccional directo. Por esta razón, la duración de las ordenanzas de necesidad ha de ser limitada en el tiempo y, mientras tanto, la Asamblea federal conserva la potestad de fiscalizar el uso y la financiación (Hottelier, 2020). 
2. EL ESTADO DE ALARMA EN EL ORDENAMIENTO JURÍDICO ESPAÑOL Y EL DEBATE SOBRE SU APLICACIÓN TRAS EL REAL DECRETO 463/2020, DE 14 DE MARZO, POR EL QUE SE DECLARA EL ESTADO DE ALARMA PARA LA GESTIÓN DE LA SITUACIÓN DE CRISIS SANITARIA OCASIONADA POR EL COVID-19

La nueva aplicación del estado de alarma en España, ahora con motivo de la pandemia de la COVID-19, ha generado un cierto debate jurídico, y también en esferas del personal político, acerca de si las medidas adoptadas en aplicación del estado de alarma podían haberse adoptado haciendo simplemente uso de la legislación ordinaria en materia de sanidad, en especial, la Ley Orgánica 3/1986, de 14 de abril, de Medidas Especiales en Materia de Salud Pública o, en un sentido opuesto, si aquellas eran en realidad más propias del estado de excepción. La controversia era importante porque, a diferencia del estado de excepción y, por supuesto, del estado de sitio, en el caso del estado de alarma ex artículo 55.1 CE no está contemplada la suspensión de derechos fundamentales ${ }^{6}$, sino su limitación y condicionamiento en el ejercicio según sea el caso, tal como se deriva de la propia Constitución (art. 116.2) y, específicamente, de la Ley Orgánica 4/1981 (art. 11)

Para abordar el alcance y los límites de los estados de alarma y excepción en tanto que modalidades del Derecho de excepción, es preciso retener la atención en los debates parlamentarios que precedieron tanto al texto constitucional como los relativos a la deliberación y aprobación de la Ley Orgánica 4/1981, reguladora de los estados excepcionales.

De sendos debates parlamentarios cabe deducir una primera conclusión: los constituyentes y, en coherencia, también el legislador orgánico, distinguieron entre el estado de alarma y el estado de excepción, subrayando que el primero estaba previsto para situaciones propias de desastres naturales mientras que el segundo estaba esencialmente concebido para hacer frente a crisis de orden político. En ambos casos siempre que los poderes públicos no pudiesen hacer frente a la situación de emergencia creada mediante las atribuciones ordinarias previstas por el ordenamiento jurídico de régimen común.

En las Cortes constituyentes, que -como es sabido- también ejercieron simultáneamente de legislador ordinario, los debates acerca del régimen jurídico que debía adoptar el estado de alarma como una modalidad específica del Derecho de excepción

6 "Artículo 55.1 CE. "Los derechos reconocidos en los artículos 17, 18, apartados 2 y 3, artículos 19, 20, apartados 1, a) y d), y 5, artículos 21 , 28, apartado 2, y artículo 37, apartado 2, podrán ser suspendidos cuando se acuerde la declaración del estado de excepción o de sitio en los términos previstos en la Constitución. Se exceptúa de lo establecido anteriormente el apartado 3 del artículo 17 para el supuesto de declaración de estado de excepción".

7 "Art. 11. Con independencia de lo dispuesto en el artículo anterior, el decreto de declaración del estado de alarma, o los sucesivos que durante su vigencia se dicten, podrán acordar las medidas siguientes: a) Limitar la circulación o permanencia de personas o vehículos en horas y lugares determinados, o condicionarlas al cumplimiento de ciertos requisitos. b) Practicar requisas temporales de todo tipo de bienes e imponer prestaciones personales obligatorias. c) Intervenir y ocupar transitoriamente industrias, fábricas, talleres, explotaciones o locales de cualquier naturaleza, con excepción de domicilios privados, dando cuenta de ello a los Ministerios interesados. d) Limitar o racionar el uso de servicios o el consumo de artículos de primera necesidad. e) Impartir las órdenes necesarias para asegurar el abastecimiento de los mercados y el funcionamiento de los servicios de los centros de producción afectados por el apartado d) del artículo cuarto". 
no fueron precisamente de gran intensidad, lo que no impide poner de relieve que lo entonces debatido tuvo especial transcendencia para definir y a su vez delimitar su contenido y límites. Inicialmente, mediante una enmienda presentada en nombre del Grupo Parlamentario Comunista por el diputado Simón Sánchez Montero y defendida por el ponente constitucional Jordi Solé Tura en la Comisión Constitucional y de Libertades Públicas del Congreso de los Diputados, se sostuvo la necesidad de la supresión de la previsión constitucional del estado de alarma (antiguo artículo 108.2 del proyecto de ley). Sus argumentos eran los siguientes: resultaba innecesario constitucionalizar el estado de alarma porque en el proyecto no se explicaban las circunstancias excepcionales que lo podían motivar (se citaban, como un ejemplo probable, situaciones propias de un cataclismo o de desastres naturales); pero para ese caso y otros similares, el Gobierno ya disponía de poderes suficientes para afrontar la situación; además, como el proyecto nada decía sobre las causas que podían motivar la declaración de la alarma, su declaración podía servir para limitar derechos, sin decirlo. En suma, era evidente que en la voluntad de la enmienda comunista subyacía el temor a dar paso a una cláusula muy abierta que otorgase al Gobierno poderes especiales por cualquier motivo o razón, motivación que la experiencia reciente y entonces muy viva de la dictadura había acreditado con creces.

La enmienda fue rechazada con el argumento de que la regulación de los estados excepcionales debía prever uno que pudiese servir para afrontar situaciones de emergencia constitucional de menor relevancia. En este sentido, el también ponente constitucional Gabriel Cisneros Laborda (UCD) sostuvo la necesidad de mantener el supuesto del estado de alarma, ya que si este se suprimía podía darse el caso, nada imprevisible, de que una situación de poca entidad debiese ser afrontada mediante la declaración del estado de excepción, cuyas consecuencias serían más gravosas para el ejercicio de la libertades, lo que resultaría paradójico con la finalidad perseguida por la enmienda de supresión. Por esta razón, proponía adecuar la respuesta a la situación de excepcionalidad a la entidad del problema creado, ya que la casuística de la alarma podía ser muy diversa, por lo que resultaba imposible tipificarla en la Constitución ${ }^{8}$. La enmienda del grupo comunista fue rechazada, pero la lógica garantista que subyacía a su contenido incidió en los debates que en 1981 se dieron con ocasión de la deliberación y aprobación de la Ley Orgánica 4/1981, reguladora de los estados excepcionales.

Esta ley fue aprobada el primero de junio de 1981, poco menos de cuatro meses después del intento de golpe de Estado del 23 de febrero de 1981, una circunstancia que, aparte de regular un aspecto tan decisivo de la Constitución como siempre es el Derecho de excepción, tras dos años y medio de vigencia de la norma normarum, la rebelión militar contra el régimen constitucional exigía de manera urgente y específica 
el inmediato desarrollo orgánico de las previsiones contempladas en los artículos 55.1 y 116 de la Constitución, dado el práctico vacío normativo existente en el momento de la asonada protagonizada activamente por una parte del ejército.

De los debates habidos con motivo de la deliberación del proyecto de ley orgánica reguladora de los estados de alarma, excepción y sitio predominó, con relación al primero de ellos, la necesidad de precisar su contenido y límites. Se trataba de evitar que, en el caso del estado de alarma, que no comportaba suspensión alguna de derechos fundamentales (art. 55.1 CE), la imprecisión o ambigüedad de su formulación legal pudiese conducir a institucionalizar un remedo de cláusula abierta a la discrecionalidad del Gobierno al afrontar situaciones de crisis. Por esta razón, de nuevo, el Grupo Parlamentario Comunista insistió a través de sus enmiendas en evitar que se diesen esas circunstancias. Así, ante una primera redacción del artículo 4 del actual artículo de la Ley Orgánica 4/1981, donde se definían las diversas alteraciones graves a la normalidad que podían dar lugar a la declaración del estado de alarma, expuestas a modo de ejemplo, utilizando la fórmula del adverbio "como" (que, por tanto, no excluía la existencia de otras no especificadas), el diputado y ponente constitucional Solé Tura propuso -esta vez, con éxito-, en pro de la seguridad jurídica en la previsibilidad de los supuestos posibles de estado alarma, la supresión del citado adverbio. De tal forma que en la actualidad el estado de alarma puede ser declarado únicamente en los cuatro supuestos previstos en el artículo $4^{9}$, y en ningún otro más.

Otra aportación del citado grupo parlamentario en la línea de precisar los supuestos del estado de alarma y de garantizar el ejercicio de los derechos fundamentales que dicho estado excepcional puede limitar pero no suspender, defendida en este caso por el diputado Nicolás Sartorius, incidió sobre una primera redacción del apartado c) del artículo 4, cuya formulación resultaba en exceso imprecisa, de tal forma que podía permitir una neutralización en el ejercicio de algunos derechos fundamentales. En efecto, en la redacción del artículo 4. c) del proyecto resultante del dictamen aprobado por la Comisión Constitucional del Congreso de los Diputados, se reputaba como causa para la declaración del estado de alarma la: "Paralización de servicios públicos esenciales para la comunidad, cuando no se garantice lo dispuesto en los artículos 28.2 y 37.2 de la Constitución": es decir, el mantenimiento de los servicios esenciales de la comunidad en caso de una huelga (art. 28.2 CE) o de conflicto colectivo promovido por empresarios o trabajadores (art. 38.2 CE).

La enmienda proponía la supresión del citado apartado c), dada la inseguridad que generaba para el efectivo ejercicio de los derechos fundamentales contemplados en ambos preceptos constitucionales. En su argumentación sostenía que la ley orgánica reguladora de los estados excepcionales no era la norma adecuada para el mantenimien-

9 Ley orgánica de los estados de alarma, excepción y sitio: trabajos parlamentarios (1984: 200) 
to de los servicios esenciales, sino que lo había de ser una futura ley orgánica reguladora del derecho de huelga. La enmienda de supresión como tal no prosperó, pero sí que lo hizo una enmienda transaccional del mismo diputado que recogía su espíritu: se mantenía el redactado del apartado c), pero con la adición del párrafo “... y concurra alguna de las demás circunstancias contenidas en este artículo". Con lo cual se aseguraba que el mero hecho de ejercer el derecho de huelga o cualquier otra medida de conflicto colectivo, individualmente considerados, no fuesen, per se, una causa para declarar el estado de alarma.

De acuerdo, pues, con el sentido de la citada enmienda transaccional, el Gobierno no puede declarar el estado de alarma para hacer frente a situaciones de conflicto social si no se producen algunas de las causas tasadas en el artículo 4 de la Ley Orgánica 4/1981. Y, más concretamente, en relación con las medidas de los apartados c $)^{10}$ y e) ${ }^{11}$ del artículo 11 de esta ley que el Gobierno puede adoptar. Ambas no pueden ser entendidas como "una 'cláusula general' que permita impartir cualquier orden considerada como necesaria bajo el estado de alarma” (Cruz Villalón, 1984: 78).

A los efectos del debate jurídico que se ha suscitado con motivo de declaración de este estado excepcional en relación con la COVID-19, en especial en lo relativo al objeto de los estados de alarma y excepción respectivamente, conviene recuperar algunos de los pasajes del debate parlamentario relativo a la Ley Orgánica 4/1981, que permiten precisar cuál fue la voluntad del legislador al respecto. Así, no hay duda de que el objeto del estado de alarma fue concebido, efectivamente, para hacer frente a desastres naturales, crisis sanitarias o circunstancias similares, mientras que el estado de excepción lo es para afrontar crisis de naturaleza política. En este sentido, en defensa de la enmienda citada, el diputado Sartorius se remitía al debate constituyente, con cita específica de la intervención del diputado y ponente constitucional Gabriel Cisneros, para afirmar que "... con la figura del estado de alarma estamos contemplando propiamente, más que situaciones de conflictividad política o social, eventos catastróficos, naturales..." (y citaba, para ilustrar con algún ejemplo, el caso en 1976 del desastre medioambiental en la población italiana de Seveso, cercana a Milán). En el mismo sentido, el diputado Luis Apostúa (UCD) subrayaba que “... el estado de alarma no es un hecho político"12.

Finalmente, pero más en el terreno de la incidencia de los estados excepcionales en la organización territorial del Estado, cabe destacar la enmienda presentada en el debate del proyecto en el Senado por el parlamentario Zabala Alcíbar, del Grupo de

10 Art. 11, c). "Intervenir y ocupar transitoriamente industrias, fábricas, talleres, explotaciones o locales de cualquier naturaleza, con excepción de domicilios privados, dando cuenta de ello a los Ministerios interesados". Sin embargo, el autor citado sostuvo entonces que este apartado sí que podía ser concebido como una cláusula general. Entiendo, por el contrario, que a la luz de la enmienda ello no ha de ser así.

11 Art. 11, e) "Impartir las órdenes necesarias para asegurar el abastecimiento de los mercados y el funcionamiento de los seruicios de los centros de producción afectados por el apartado d) del artículo cuarto".

12 Estados de alarma, excepción y sitio. Op. cit., p. 201. 
Senadores Vascos, por la que se proponía que la Comunidad Autónoma fuese consultada "... únicamente cuando el estado de alarma afecta a una Comunidad Autónoma, no cuando afecta a dos o más Comunidades Autónomas". La enmienda entraba razonablemente en la lógica que habría de presidir la colaboración en el marco de un Estado compuesto como el que prefiguraba la Constitución. No obstante, sería rechazada ${ }^{13}$. A pesar de ello, el artículo 5 de la Ley Orgánica 4/1981 supuso un cierto cambio de rumbo, dado que atribuyó capacidad de impulso a la Comunidad Autónoma en el supuesto siguiente: "Cuando los supuestos a que se refiere el anterior afecten exclusivamente a todo o parte del ámbito territorial de una Comunidad Autónoma, el Presidente de la misma podrá solicitar del Gobierno la declaración de estado de alarma”. No era lo mismo, ciertamente, pero reconocía entidad a la Comunidad Autónoma para incitar al Gobierno del Estado a ejercer una competencia constitucional que únicamente a él le está atribuida.

Con los mimbres que aportan los, por otra parte, reducidos debates parlamentarios sobre el contenido y los límites del estado de alarma en el proceso constituyente, y los habidos con ocasión de la aprobación de la Ley Orgánica 4/1981, se ha afrontado la segunda ocasión en la que ha tenido que ser declarado por el Gobierno. La primera lo fue, como se ha señalado, en diciembre de 2010, a causa de la huelga encubierta de los controladores aéreos. Pero ha sido en la segunda ocasión, motivada por la descontrolada expansión mundial de la pandemia de la COVID-19, que los problemas de orden jurídico se han planteado con toda crudeza tras la declaración del estado de alarma mediante el Real Decreto 463/2020, de 14 de marzo, y las sucesivas seis prórrogas acordadas por el Congreso de los Diputados cada quince días, hasta la pérdida de vigencia del estado de alarma a las cero horas del día 21 de junio de 2020.

La controversia jurídica ha girado alrededor de diversos temas que pueden ser resumidos en tres: la inicial consideración por parte de las autoridades representativas de algunas comunidades autónomas (CC.AA.), aunque se mantuvo viva muy poco tiempo, que el estado de alarma suponía de hecho la aplicación de la coerción estatal ex artículo 155 CE sobre la capacidad de autogobierno de las comunidades autónomas. El segundo giró en torno a la idea según la cual las medidas contenidas en el Real Decreto 463/2020, de 14 de marzo, por el que se declaraba el estado de alarma, eran constitucionalmente improcedentes, en especial las referidas a la libertad de circulación y residencia, razón por la cual en realidad se habría tenido que declarar el estado de excepción. Y finalmente, el tercero ha versado sobre la compleja distinción entre limitación y suspensión de derechos que se deriva según se declare el estado de alarma o el estado de excepción. 


\section{LA COERCIÓN ESTATAL EX ART. 155 Y EL ESTADO DE ALARMA EX ARTS. 55.1 CE Y $116.2 \mathrm{CE}$}

La imputación al estado de alarma de ser una forma de coerción estatal ex artículo 155 CE carecía de sentido jurídico. La institución constitucional del artículo 155 CE nada tiene que ver con las previsiones de Derecho excepcional previstas en los artículos 55.1 y 116 CE. Fue incorporada por el constituyente como una cláusula de reserva o de cierre del sistema de controles del Estado sobre las comunidades autónomas. Su formulación fue parca y es positivo que así lo sea porque de lo que se trata con este procedimiento de ejecución, una vez agotadas otras vías, es de compeler a una comunidad autónoma a cumplir con la Constitución y las leyes.

Junto con la regulación de los estados excepcionales (art. 116 CE) y de la legislación material de urgencia (art. 86 CE), la coerción estatal es una manifestación específica del Derecho constitucional de excepción prevista como ultima ratio para un supuesto específico de conflicto territorial entre el Estado y una comunidad autónoma (García Torres, 2019: 114): cuando esta última incumple con sus obligaciones constitucionales. Es en el hecho de formar parte del Derecho de excepción donde se acaban las similitudes entre la coerción y el estado de alarma.

Desde los estudios iniciales sobre la organización del régimen jurídico de las CC.AA. se registró unanimidad en considerar que la coerción estatal por parte del Estado sobre las CC.AA. es un instrumento de carácter extraordinario de resolución de conflictos entre ambas partes (Albertí, 1985: 471). De tal forma que, concibiéndolo así, no puede ser entendido como una especie de última instancia de los procedimientos constitucionales para resolver los conflictos de competencia entre el Estado y las CC.AA. Se trata de cosa bien distinta a un procedimiento ordinario de inspección consecuencia de unos supuestos de poderes previos de vigilancia o inspección, de los que carece el Estado según el modelo constitucional español. Nada que se asemeje a ello. La ejecución forzosa estatal no puede derivarse de la información que el Gobierno haya podido disponer sobre la actuación de una comunidad autónoma, obtenida mediante dicha inspección o supervisión estatal sobre la ejecución autonómica de la legislación del Estado, como se sostuvo en su momento (García de Enterría, 1983: 172-173).

Por otra parte, la coerción estatal que ha de afrontar una situación extrema por el incumplimiento de las obligaciones constitucionales por parte de una comunidad autónoma, tampoco presupone una posición previa de superioridad o jerarquía del Gobierno central sobre la comunidad autónoma. La inspección estatal y la compulsión ejercida por el Estado sobre las CC.AA. son dos figuras distintas (Gil Robles y Gil Delgado 1999: 511) que impiden deducir la coerción como una lógica consecuencia de un inexistente poder de inspección ordinario del Estado sobre las CC.AA. Cuestión distinta es que el carácter extraordinario del instituto de la coerción permite -sin dudaal Estado situarse temporalmente en una posición de mayor disponibilidad ejecutiva sobre el marco competencial diseñado por el bloque de la Constitución, sobre la acción 
y los actos de las instituciones de la comunidad autónoma. Pero siempre bajo las condiciones de sujeción al procedimiento y control tanto parlamentario como jurisdiccional. Por tanto, con capacidad para intervenir sobre el autogobierno de la comunidad autónoma. Dicho lo cual, la coerción estatal no es ni puede ser sinónimo de una atribución siquiera provisional de plenos poderes al Estado. En consecuencia, la redefinición del ámbito de la autonomía política que conlleva la ejecución estatal forzosa en ningún caso exonera al Estado de toda sujeción a la Constitución (Álvarez, 2016: 295). El bien jurídico protegido ex artículo $155 \mathrm{CE}$ es la garantía del orden constitucional: el respeto a la Constitución y al resto de las leyes que hayan sido vulneradas. Algo muy distinto a lo que se pretende con el estado alarma como una de las modalidades de Derecho de excepción, que no es otra que atribuir al Estado poderes especiales, como en el caso de la COVID-19, para afrontar una crisis sanitaria con la colaboración de las.

\section{LIMITACIÓN Y SUSPENSIÓN DE DERECHOS: ¿ESTADO DE ALARMA O ESTADO DE EXCEPCIÓN?}

A escasos días de que el Gobierno adoptase la decisión de decretar el estado de alarma mediante el Real Decreto 463/2020, de 14 de marzo, por el que se declara el estado de alarma para la gestión de la situación de crisis sanitaria ocasionada por el COVID-19, tanto en la prensa escrita como digital, así como también en alguna publicación académica periódica, menudearon comentarios en el orden jurídico a la decisión del Gobierno para hacer frente la pandemia ${ }^{14}$.

La amplia mayoría de las colaboraciones citadas sostuvieron que la declaración del estado de alarma contenida en las medidas contempladas en el Real Decreto 463/2020, de 14 de marzo, disponían de suficiente cobertura constitucional. El argumento central, con matices diversos, sostenía por un lado que el estado de alarma ex artículos 116.2 CE y $4^{\circ}$. b) de la Ley Orgánica 4/1981 está previsto para hacer frente a "Crisis sanitarias, tales como epidemias y situaciones de contaminación graves”; y, por otro, que, de acuerdo con el artículo 55.1 CE y a diferencia de los estados de excepción y sitio, del estado de alarma no se deriva suspensión alguna de derechos fundamentales. Alguno de los autores citados invocaba, además, en apoyo de esta tesis, la STC 83/2016, de 28 de abril (FJ, 8), dictada con ocasión de un recurso de amparo relativo a la declaración del estado de alarma debido a la huelga encubierta de controladores aéreos en 2010, en la que el Tribunal Constitucional distinguió entre restringir o limitar un derecho (estado de alarma) y suspenderlo (estados de excepción y sitio).

14 Seguramente, uno de los primeros fue el número monográfico de la Revista El cronista del Estado Social y Democrático de Derecho no 86-87, marzo-abril 2020

Al mismo siguieron un amplio catálogo de publicaciones en la prensa diaria escrita y en la digital entre marzo y abril de 2020, de las que, entre otras, cabe retener los artículos escritos por: T. de la Cuadra Salcedo, M. Aragón Reyes, P. Cruz Villalón, S. Muñoz Machado, J. A. García Sáez, M. A. Presno Linera, J. Urías y yo mismo. 
En esta sentencia el Tribunal desestimó el amparo solicitado por los controladores aéreos por presunta lesión de un amplio catálogo de derechos fundamentales [el derecho a la tutela judicial efectiva (art. 24.1 CE); el derecho al juez ordinario predeterminado por la ley (art. 24.2 CE); la libertad de expresión (art. 20 CE); la libertad de reunión y manifestación (art. $21 \mathrm{CE}$ ); la libertad de afiliación política y sindical (art. $22 \mathrm{CE}$ ); el derecho de sufragio pasivo (art. $23 \mathrm{CE}$ ); la libertad sindical y el derecho de huelga (art. $28 \mathrm{CE}$ ) y el derecho de petición (art. 29 CE)]. Además también rechazó la pretensión de los recurrentes sobre los elementos reglados del acto, dado que consideraban que no concurrían los presupuestos para la declaración del estado de alarma. El Tribunal estableció una argumentación para fundamentar la compleja distinción entre restricción o limitación y suspensión de derechos en los siguientes términos:

A diferencia de los estados de excepción y de sitio, la declaración del estado de alarma no permite la suspensión de ningún derecho fundamental (art. 55.1 CE contrario sensu), aunque sí la adopción de medidas que pueden suponer limitaciones o restricciones a su ejercicio. En este sentido, se prevé, entre otras, como medidas que pueden ser adoptadas, la limitación de la circulación o permanencia de personas o vehículos en lugares determinados o condicionarlas al cumplimiento de ciertos requisitos; la práctica de requisas temporales de todo tipo de bienes y la imposición de prestaciones personales obligatorias; la intervención y la ocupación transitoria de industrias, fábricas, talleres, explotaciones o locales de cualquier clase, con excepción de domicilios privados; la limitación o el racionamiento del uso de servicios o del consumo de artículos de primera necesidad; la adopción de las órdenes necesarias para asegurar el abastecimiento de los mercados y el funcionamiento de los servicios de los centros de producción afectados por una paralización de los servicios esenciales para la comunidad cuando no se garanticen los servicios mínimos; y, en fin, la intervención de empresas o servicios, así como la movilización de su personal, con el fin de asegurar su funcionamiento, siéndole aplicable al personal movilizado la normativa vigente sobre movilización (...). (FJ 8)

Pero lo cierto es que la resolución del Tribunal no arrojó mucha luz para ilustrar dicha distinción -por otra parte nada sencilla- sobre lo que debería significar restricción versus limitación y suspensión de derechos. En realidad lo hizo de forma más bien apodíctica, limitándose a describir reproduciendo el contenido del artículo 11 de la Ley Orgánica 4/1981 relativo a las medidas que en aplicación del estado de alarma pueden adoptar los poderes públicos. Renunció a adentrarse en un terreno ciertamente complejo, al objeto de establecer algún criterio interpretativo que ayudase a delimitar el alcance de la restricción de derechos y mirar de fijar un punto de no retorno, en el que la restricción deja de serlo para pasar a ser una efectiva suspensión.

Seguramente la solución tópica y poco útil en este sentido pudiese haber consistido en establecer que la restricción versus limitación no podía afectar al contenido esencial del derecho, en tanto que núcleo duro o intangible del derecho fundamental. Sin duda, se trata de una solución fácil por la acreditada dificultad de determinar en 
realidad en qué consiste la referencia al contenido esencial ex artículo 53.1 CE como límite a la capacidad de disposición del legislador. Pero, en todo caso, esta u otra solución menos retórica hubiese sido más útil al objeto de dar pleno sentido constitucional -que sin duda lo tiene, como manifestó también el legislador constituyente- al estado de alarma. Una modalidad de Derecho de excepción diferenciada del estado de excepción concebida para hacer frente a las diversas situaciones de emergencia que pueden producirse, pero en las que el orden público no es el bien jurídico a proteger sino que lo puede ser la salud pública por causa de una epidemia, la preservación del medio ambiente ante incendios, inundaciones o cualquier otro desastre natural, el abastecimiento de productos de primera necesidad, etc.

En la primera fase del debate jurídico, en las colaboraciones de urgencia de los dos primeros meses de vigencia del estado de alarma, se ponía énfasis en que la declaración del estado de alarma nada tenía que ver con la aplicación de la coerción estatal ex artículo 155 CE, que dicha modalidad de Derecho de excepción no suspende el régimen autonómico de competencias sino que el Estado asume algunas de forma temporal; que, técnicamente, el Real Decreto 463/2020 no es un estado de excepción sino un estado de alarma, que no deja de ser una situación extraordinaria que:

... sin suspender el régimen normal de competencias, permite al Estado, a los solos efectos de solucionar los graves problemas derivados de la pandemia, asumir temporalmente todas las competencias (...). Esa asunción temporal de competencias no solo es perfectamente constitucional porque lo prevea el artículo 116 de la Constitución, sino porque es conforme con una interpretación sistemática de esta, en cuanto no altera el orden normal y permanente de competencias que sigue igual. [De la Quadra Salcedo (I), 2020: 9]

Con relación al régimen de los derechos y libertades y sus límites, algunos de los autores que han avalado la adecuación del estado de alarma como instrumento constitucional, con remisión a la STC 83/2016, han sostenido que en el estado de alarma no puede haber suspensión de derechos fundamentales. Para ilustrar esta regla interpretativa para el caso concreto de la situación de pandemia, se ha argumentado, por ejemplo, que "nadie puede considerar que someter a cuarentena -en un centro médico o en su propio domicilio, en su caso- a un pasajero de un avión o barco con una enfermedad gravemente contagiosa (recuérdese el ébola) signifique 'suspenderle' sus derechos fundamentales" [De la Quadra Salcedo (II), 2020: 9). Y en relación con las invocaciones en favor de la aplicación del estado excepción para el caso de las medidas previstas por el Real Decreto 463/2020, el citado autor sostuvo también que:

... aplicar el estado de excepción a situaciones motivadas exclusivamente por acontecimientos naturales o tecnológicos supondría una modalidad de violación constitucional: un fraude de ley y, en último extremo, de Constitución. (...) (...) Los supuestos del estado de alarma no tienen carácter político, y los del estado de alarma, sí. [De la Quadra Salcedo (III), 2020: 9] 
Esta posición contrasta con aquellas otras que consideraron que, por el contrario, el Gobierno estaba haciendo un uso exorbitante del estado de alarma no solo para "legitimar la anulación del control parlamentario", [sino también para]:

... a su amparo decretar, como se ha hecho, la suspensión generalizada del derecho de libertad de circulación y residencia de los españoles medida que solo puede adoptarse en el estado de excepción, como determina el artículo 55.1 de la Constitución". [Y a mayor abundamiento]: "[O]rdenar una especie de arresto domiciliario de la inmensa mayoría de los españoles, que es lo que realmente se ha hecho, no es limitar el derecho, sino suspenderlo y esa conclusión resulta difícilmente rebatible desde un entendimiento jurídico correcto, y en tal sentido la medida adoptada creo que es bien distinta de la normativamente estipulada para el estado de alarma. Sí se corresponde con el estado de excepción que tiene prevista esa posibilidad de suspensión en el artículo 55.1 de la Constitución y en el artículo 29 de la Ley Orgánica 4/1981. (Aragón, 2020: 9)

En una línea distinta, pero con alguna coincidencia en el sentido de considerar que resulta innegable "la laminación a la que se están sometiendo los derechos y libertades", otro autor consideró que, no obstante, "el problema constitucional que se ha planteado con la declaración del estado de alarma para combatir la Covid-19 no radica en si hubiera sido más procedente declarar el estado de excepción sino en los límites de los poderes gubernamentales de emergencia”. En este sentido, subrayaba la necesidad de someter los poderes del Gobierno a los límites de temporalidad y proporcionalidad en su aplicación (Muñoz Machado, 2020: 11).

En la lógica de atribuir un sentido constitucional al estado de alarma como soporte a la situación creada por la pandemia, se encuentra la posición sostenida por un antiguo presidente del Tribunal Constitucional: sin perjuicio de reconocer que la dura realidad que ofrece la emergencia es de tal magnitud “... que difícilmente podríamos encontrar acabadamente reflejada en ninguno de los estados de emergencia previstos, sea el estado de alarma, el de excepción o el de sitio", el autor retuvo la atención en las diferencias sustantivas entre el estado de alarma y el de excepción, con el argumento siguiente: en relación con la pandemia y la respuesta dada por el Gobierno, el autor sostuvo -en una larga cita que, no obstante, es preciso reproducir- que:

... hemos podido disponer de un instituto concebido para catástrofes de este tipo, bajo el que acoger las drásticas pero necesarias medidas adoptadas. La patente restricción resultante en el ejercicio de algunos derechos fundamentales ha hecho dudar de la idoneidad de la opción por este preciso estado de emergencia, que por lo que hace a su alcance y a diferencia de los estados de excepción o de sitio, no permite la suspensión de derecho fundamental alguno. Ocurre, sin embargo, que el estado de excepción, tal como nuestro ordenamiento lo configura, es expresión y respuesta a un conflicto político abierto. Sería concebible un estado de excepción superpuesto al de alarma en una situación de amplio desafío a este último, pero esto en modo alguno ha ocurrido, de tal modo que sería incluso injusto revestir con los caracteres de una emergencia de orden público unas medidas tan generalmente acatadas por la población (Cruz Villalón, 2020: 9). 
En un sentido similar, se ha señalado también que la pandemia ha ocasionado en España un gravísimo problema sanitario, con amplia trascendencia en el ámbito familiar, laboral, social, etc., “... pero no tenemos un problema de orden público” (Presno Linera, 2020: 3).

De esta serie de reflexiones producidas en las primeras semanas de las medidas de emergencia adoptadas, cabe destacar, sobre todo, la principal de ellas, que es la referida a la adecuación o procedencia constitucional de decretar el estado de alarma. Junto a esta, aparecen los poderes atribuidos al Gobierno para su ejecución y también la incidencia en el sistema de distribución de competencias en un modelo de Estado compuesto como es el diseñado por la Constitución, tema este que merecería una atención específica pero que queda al margen del objeto de este artículo.

El sentido y la finalidad del estado de alarma como una de las modalidades constitucionales del Derecho de excepción quedaron establecidos en el debate constituyente. Lo que se pretendía no era abordar problemas de orden público, sino dotar a las instituciones del Estado y, en especial, al Gobierno y al Congreso de los Diputados, de un instrumento jurídico que les permitiese adoptar decisiones especiales para afrontar hechos imprevistos originados por desastres naturales, crisis sanitarias, situaciones de desabastecimiento, paralización ilegal de los servicios públicos, etc. La identidad del estado de alarma como Derecho de excepción expresada en los debates constituyentes era esa, y no una emergencia política ocasionada por alteraciones del orden público que impidan el libre ejercicio de los derechos y libertades y el normal funcionamiento de las instituciones representativas o que ocasione una alteración grave de los servicios públicos.

En el caso de la pandemia de la COVID-19, el orden público no ha sido lesionado, ni tampoco ha impedido el funcionamiento de las instituciones, más allá de las lógicas limitaciones en el contacto físico aplicables a los representantes políticos al igual que al resto de ciudadanos. La alteración producida ha sido otra muy distinta, y ha afectado al sistema sanitario del país y a la salud de las personas. Éste ha sido el orden alterado y no otro (Carrillo, 2020: 6).

Con el estado de alarma, lo que el constituyente pretendió fue articular una forma especial de intervención del poder público para situaciones que, aun siendo complejas o incluso graves, no exijan la adopción de medidas tan drásticas que anulen a radice el ejercicio de los derechos fundamentales de la ciudadanía. La razón del estado de alarma es, en este sentido, abrir la puerta a la potestad del poder público para disponer de margen de maniobra que le permita adoptar medidas graduales y proporcionadas a la gravedad de los hechos que ha de afrontar. Un tipo de medidas que no estén relacionadas con el orden público, entendido este como sinónimo del orden en la vía pública. Y, por tanto, como de forma precisa establece el artículo 4. c) de la Ley Orgánica 4/1981, en ningún caso el estado de alarma puede servir como una vía autónoma para afrontar la conflictividad social (política, laboral, económica, etc.). 
O, más concretamente, el estado de alarma no puede servir para afrontar, por ejemplo, los problemas derivados de la convocatoria legal de una huelga (art. 28.2 CE) o la adopción, conforme a la legislación sectorial, de medidas empresariales de conflicto colectivo (art. 37.2 CE) de reordenación y reajuste de la plantilla laboral ante una crisis económica del sector o por cese de la actividad empresarial, con las consecuencias sociales y económicas que en ambos casos se puedan generar. En estos casos el Gobierno no podrá aprovechar la oportunidad para recurrir al estado de alarma, salvo en el supuesto de que estas situaciones de conflicto laboral/empresarial se produzcan de forma paralela en el contexto de una catástrofe natural, crisis sanitaria, paralización de los servicios públicos esenciales de la comunidad. Este fue el sentido de la enmienda del grupo comunista durante el debate de la Ley Orgánica $4 / 1981$.

El orden público sobre el que se proyecta la aplicación del estado de excepción, y no así el estado de alarma, es un concepto jurídicamente indeterminado de uso polivalente y frecuente en las diversas ramas del Derecho. Así, opera en el ámbito del Derecho civil, por ejemplo, para limitar los pactos, cláusulas y condiciones en los contratos privados (art. $1555 \mathrm{CCv}$.). O también en el Derecho penal, para tipificar el delito de desórdenes públicos (art. $557 \mathrm{CP}$ ). En Derecho administrativo el concepto de orden público es empleado, entre otros casos, para precisar la entidad de los vicios que pueden ocasionar que un acto administrativo sea nulo de pleno derecho. Pero para lo que ahora es de interés para el objeto de este trabajo y en este mismo ámbito del Derecho, existe un concepto de orden público distinto al anterior y que, como se ha señalado, responde por su similitud con la

... tranquilidad material, de orden en la calle (...) de ausencia, en suma, de perturbaciones a la tranquilidad. Vertiente ésta del orden público que automáticamente remite a la actuación gubernativa y a las potestades policiales con que el ordenamiento habilita a la Administración pública sobre la materia, así como, cambiando de plano pero con coincidencia en lo sustancial, a las eventuales consecuencias penales del delito de desórdenes públicos... (Barcelona Llop, 1995: 4631).

Esta noción del orden público habitual en los sistemas democráticos como sinónimo de tranquilidad material fue, sin embargo, especialmente utilizado de forma genérica, tergiversada, y por tanto abusiva en las diversas formas de gobierno autoritarias y dictatoriales que han jalonado la historia de la conformación del Estado español contemporáneo. La Constitución y su legislación de desarrollo se desvincularon de esta tradición. Así, en el orden jurídico-constitucional actual el concepto de orden público como límite al ejercicio de los derechos fundamentales también está previsto por la norma suprema, por ejemplo, en relación con los derechos a la libertad religiosa (art. 16.2 CE) y el derecho de reunión y manifestación (art. 21.2 $\mathrm{CE}$ ), como una forma de hacer compatible la libertad del ciudadano con el inte- 
rés colectivo. Cobra, por tanto, una nueva dimensión en la que la preservación del orden público ya no puede suponer una habilitación general para limitar el ejercicio de derechos fundamentales sino un límite interpretado de forma restrictiva. En consecuencia, la noción de orden público no tiene otro sentido “... que el de su íntima conexión con el libre ejercicio de los derechos fundamentales y libertades públicas, protección que es la que justifica que la Administración, básicamente la Administración de la seguridad pública ostente potestades que de otro modo carecerían de justificación" (Barcelona Llop, 1095: 4634). Unas potestades que, en todo caso, sean en una situación ordinaria o excepcional, nunca podrán quedar exentas de control jurisdiccional.

Esta noción de orden público es a la que el legislador constituyente fijó su atención para configurar el estado de excepción de manera diferenciada del estado de alarma. Y es a la que se refiere el artículo 13.1 de la Ley Orgánica 4/1981, en el que se define su objeto ${ }^{15}$. Sin que las circunstancias que han rodeado a la propagación de la pandemia en España y el establecimiento del estado de alarma permitan colegir que se hayan registrado los supuestos a los que se refiere dicho precepto legal relacionado con la preservación del orden público.

El orden público es un presupuesto ineludible para el libre ejercicio de los derechos y libertades (Cruz Villalón, 1984: 84). La emergencia ocasionada por la pandemia ha comportado una muy grave afectación a la salud de muchas personas y ha afectado a la capacidad de resistencia del sistema sanitario, pero no ha sido un problema de orden público el que ha comportado la limitación del ejercicio de determinados derechos, sino la necesidad de preservar la salud colectiva. Asimismo, hasta la aparición del problema sanitario las instituciones representativas y judiciales ejercían sus funciones normativas y de control parlamentario de forma regular. Y lo mismo había que decir del normal funcionamiento de los servicios públicos esenciales para la comunidad. No ha sido, pues, la seguridad pública en la calle lo que ha causado el estado de alarma, sino una crisis sanitaria calificada por la Organización Mundial de la Salud como una pandemia, de origen hasta hoy no determinado científicamente. En consecuencia, y a la luz del ordenamiento constitucional y legal vigentes, en nada resulta convincente deducir, de las limitaciones y restricciones sobre derechos y libertades prescritas en el Real Decreto 463/2020, de 14 de marzo, que lo que procedía era decretar el estado de excepción.

Una cuestión distinta en la aplicación del estado de alarma que exige centrar la atención es la concerniente al ejercicio por el Gobierno de los poderes especiales

15 "Uno. Cuando el libre ejercicio de los derechos y libertades de los ciudadanos, el normal funcionamiento de las instituciones democráticas, el de los servicios públicos esenciales para la comunidad, o cualquier otro aspecto del orden público, resulten tan gravemente alterados que el ejercicio de las potestades ordinarias fuera insuficiente para restablecerlo y mantenerlo, el Gobierno, de acuerdo con el apartado tres del artículo ciento dieciséis de la Constitución, podrá solicitar del Congreso de los Diputados autorización para declarar el estado de excepción". 
de los que dispone en virtud del estado de alarma, en especial la adecuación de sus actuaciones al principio de proporcionalidad. Conforme al mismo, la intervención limitativa que el legislador o, en general, el autor de la norma, lleven a cabo sobre un derecho fundamental debe quedar justificada por la relevancia que presente la finalidad que persiga la intervención normativa. Las ventajas que dicha intervención comporte sobre el derecho o derechos fundamentales afectados habrán de compensar los sacrificios (limitaciones y restricciones) que los titulares del derecho y, en general, la sociedad ha de soportar. Si en esa ponderación de intereses en conflicto, entre la defensa de la libertad personal y la garantía del interés colectivo llevada a cabo por un órgano jurisdiccional, primase el derecho afectado, la norma sería inconstitucional. Si por el contrario la prioridad correspondiese al interés general necesitado de protección, la disposición interventora sería adecuada a la Constitución (Bernal Pulido, 2007: 763-764).

El juicio o test de proporcionalidad de una medida interventora sobre derechos fundamentales reside, en primer lugar, en determinar si la misma resulta necesaria para afrontar la concreta situación de hecho que la ha provocado; seguidamente, si la medida adoptada es idónea a la finalidad perseguida sin que, por tanto, exista otra menos gravosa sobre el derecho fundamental y, finalmente, si ello es así será preciso examinar strictu sensu si, en efecto, es proporcional o, por el contrario, desmesurada. A este respecto, y como reiteradamente ha puesto de manifiesto el Tribunal Constitucional desde los inicios de su actividad jurisdiccional, como tribunal supremo de los derechos fundamentales, ha sido precisamente este ámbito del Derecho constitucional donde el juicio de proporcionalidad se ha aplicado con asiduidad:

Así ha venido reconociéndolo este Tribunal en numerosas Sentencias en las que se ha declarado que la desproporción entre el fin perseguido y los medios empleados para conseguirlo puede dar lugar a un enjuiciamiento desde la perspectiva constitucional cuando esa falta de proporción implica un sacrificio excesivo e innecesario de los derechos que la Constitución garantiza (...) SSTC 62/1982 (...) STC 19/1988 (...) STC 66/1955. [STC 136/1999, de 20 de julio, FJ 22]

En consecuencia, habrá de ser esencialmente con estos mimbres con los que proceda examinar el alcance de la afectación que, entre otras, hayan tenido las medidas de limitación o restricción contenidas en el Real Decreto 463/2020, de 14 de marzo, por el que se decretó el estado de alarma. 


\section{LA LIBERTAD DE CIRCULACIÓN Y EL DERECHO DE REUNIÓN Y MANIFESTACIÓN}

La limitación de la libertad de circulación de personas, prevista en el artículo 7 del Real Decreto 463/2020, de 14 de marzo, por el que se declaró el estado de alarma ${ }^{16}$, suscitaron la crítica en determinados sectores del ámbito político y algo menos en el jurídico, al considerar que en realidad lo que significaban era una suspensión del derecho fundamental a la libertad de circulación (art. 19 CE). Pocas semanas después, y cuando el Congreso ya había aprobado algunas de las prórrogas del estado de alarma, la crítica se extendió también a algunas decisiones adoptadas por autoridades gubernativas de no autorizar por razones sanitarias la realización de manifestaciones. En algunos casos la jurisdicción ordinaria entendió que se vulneraba el derecho de reunión y manifestación (art. $21 \mathrm{CE})^{17}$.

Atendiendo a la interrelación entre ambos derechos fundamentales, en especial por la vinculación que presenta la libertad de circulación y de transitar por la vía pública que comporta el derecho de manifestación, el examen de las cuestiones controvertidas en el orden jurídico, suscitadas tanto por las decisiones gubernativas como las jurisdiccionales, demandan en este caso un tratamiento conjunto de ambos derechos. Porque más allá de su objeto y especificidad, los derechos fundamentales no pueden ser concebidos como compartimentos estancos. Un caso paradigmático lo constituyen la libertad de circulación y el derecho de manifestación, que es una forma de tránsito de personas en la vía pública, congregadas para expresar unas ideas o dar a conocer a la sociedad una posición.

16 “Artículo 7. Limitación de la libertad de circulación de las personas.

1. Durante la vigencia del estado de alarma, las personas únicamente podrán circular por las vías o espacios de uso público para la realización de las siguientes actividades, que deberán realizarse individualmente, salvo que se acompañe a personas con discapacidad, menores, mayores, o por otra causa justificada:

a) Adquisición de alimentos, productos farmacéuticos y de primera necesidad, así como adquisición de otros productos y prestación de servicios de acuerdo con lo establecido en el artículo 10

b) Asistencia a centros, servicios y establecimientos sanitarios.

c) Desplazamiento al lugar de trabajo para efectuar su prestación laboral, profesional o empresarial.

d) Retorno al lugar de residencia habitual.

e) Asistencia y cuidado a mayores, menores, dependientes, personas con discapacidad o personas especialmente uulnerables.

f) Desplazamiento a entidades financieras y de seguros.

g) Por causa de fuerza mayor o situación de necesidad.

h) Cualquier otra actividad de análoga naturaleza".

17 Estos supuestos se dieron en situaciones y motivaciones distintas: en unos casos, las manifestaciones convocadas algunos sindicatos tenían que ver con la tradicional celebración del 1ํ de mayo; en otras fueron convocatoria promovidas por partidos políticos de oposición al Gobierno central por la declaración y/o la gestión del estado de alarma. En el momento de finalizar la redacción de este trabajo (agosto 2020), permanece sub iudice la resolución del recurso de inconstitucionalidad no 2054-2020, contra los artículos 7, 9, 10 y 11 del Real Decreto 463/2020, presentado por el partido de extrema-derecha VOX. 
La libertad de circulación.

El derecho a circular libremente por el territorio español, la libertad del ciudadano de trasladarse de un sitio o a otro, o simplemente de deambular, comporta la obligación del poder público de abstenerse y de no injerirse en la libre decisión de la persona de ir para aquí o para allá. Para que esta injerencia sea legítima, es preciso que goce de habilitación legal expresa (entre otras, las SSTC 169/2001, de 16 de julio, FJ 6; 184/2003, de 23 de octubre, FJ 6 b) [Losada González, 2018: 572]. Entre las intromisiones que la Constitución y la ley pueden permitir, con carácter general se encuentran: la declaración de cualquiera de los estados excepcionales regulados por la citada Ley Orgánica 4/1981; a fin de preservar la seguridad pública, la Ley Orgánica 5/2025, de 30 de marzo, de protección de la seguridad ciudadana; o, más específicamente, en materia de extranjería, la Ley 4/2000, sobre derechos y libertades de los extranjeros en España, que prevé limitaciones temporales en relación precisamente con personas extranjeras.

Pues bien, la habilitación constitucional y legal de las medidas restrictivas de la libertad o de naturaleza limitativa de la circulación (Álvarez García, 2020: 16) previstas en el artículo 7 del Real Decreto 463/2020, se encuentran en primer lugar en la Constitución (art. 116.2) y seguidamente en la Ley Orgánica 4/1981 [arts. 4.b) y 11. a)]. En la medida en que la situación sanitaria creada por la COVID-19 fue calificada como pandemia, que en el caso español, como en muchos otros Estados, se había propagado por todo el territorio, la potestad para adoptar medidas -no individuales y de carácter general- restrictivas de derechos, sin distinción administrativa de ámbito territorial de aplicación, correspondían al Estado (Barnes Vázquez, 2020:9) y, en consecuencia, eran estas y no otras las normas prima facie aplicables. Ergo, la declaración del estado de alarma era insoslayable y sus consecuencias no podían ser suplantadas por otras disposiciones a extramuros del Derecho de excepción.

Ello sin perjuicio de que, respecto de las medidas a adoptar específicamente en el sector sanitario, pudiesen también invocarse, pero de forma complementaria y no alternativa, las previsiones establecidas en el artículo 3 de la Ley Orgánica 3/1986, de 14 de abril, de Medidas Especiales en Materia de Salud Pública ${ }^{18}$. Sobre todo, para adecuar la gestión de las medidas sanitarias a las competencias de las CC.AA. en materia de sanidad, en coordinación con el Estado (art. 149.1.16 CE).

La limitación o restricción de la libertad de circulación prescrita en el artículo 7 del Real Decreto 463/2020 no constituyó una suspensión del derecho fundamental que impidiera en todo caso su ejercicio. La propia gradación de su aplicación a través de las conocidas fases organizadas por la coordinación estatal del proceso, que oscilaron entre la fase 0 y la fase 4 , permite determinar que las restricciones se adoptaron en

18 "Artículo tercero. Con el fin de controlar las enfermedades transmisibles, la autoridad sanitaria, además de realizar las acciones preventivas generales, podrá adoptar las medidas oportunas para el control de los enfermos, de las personas que estén o hayan estado en contacto con los mismos y del medio ambiente inmediato, así como las que se consideren necesarias en caso de riesgo de carácter transmisible". 
función de la extensión e intensidad de la contaminación del virus. Y que, incluso, en la fase inicial de aplicación de las medidas no quedó impedida la libertad del ciudadano para, por ejemplo, adquirir alimentos, productos farmacéuticos, la asistencia a centros sanitarios, desplazarse al lugar de trabajo en aquellos casos en los que la actividad se considerara esencial para la comunidad.

Como se ha tratado de argumentar supra, con la modalidad de Derecho de excepción que es el estado de alarma, el legislador constituyente pretendió organizar una forma especial de intervención del Estado para situaciones de crisis complejas o graves, sin que para hacerle frente hubiere que provocar el impedimento total del ejercicio del derecho. Las medidas contenidas en artículo 7 y otros preceptos conexos del Real Decreto 463/2020 respondieron, efectivamente, a esta lógica.

\section{El derecho de manifestación.}

Quizás, los efectos de las medidas para combatir la pandemia han planteado una faceta jurídica más controvertida con relación al ejercicio del derecho de manifestación. Porque, si como ha señalado la jurisprudencia constitucional, la declaración del estado de alarma comporta restricciones o limitaciones de derechos pero no su suspensión (STC 83/2016, FJ 8), quizás podría resultar paradójico el impedimento gubernativo para llevar a cabo una manifestación solicitada formalmente, fundado en la necesidad de preservar la salud colectiva y la integridad del sistema sanitario. Ahora bien, es una paradoja que resulta más bien relativa porque se haya o no declarado el estado de alarma, esto es, tanto en una situación de normalidad como de excepcionalidad, y como prescribe la Constitución, las “... reuniones en lugares de tránsito público (...) la autoridad (...) podrá prohibirlas cuando existan razones fundadas de alteración del orden público, con peligro para personas o bienes" (art. 21.2).

El derecho de manifestación es una modalidad de reunión que se caracteriza por la esporádica congregación de personas en el espacio público, al objeto de mostrar ante las instituciones representativas y el entorno social unas ideas, opiniones o una postura sobre temas de interés sectorial o general, a fin de reclamar su atención al respecto. Por esta razón, el derecho de manifestación se relaciona, sobre todo, con la libertad de expresión y de forma instrumental -como hemos visto- con la libertad de circulación de los participantes en la concentración. Aunque la manifestación comporte o pueda comportar una molestia o una limitación para la libertad de circulación del resto de transeúntes que no participan en ella.

Acerca de las limitaciones al ejercicio del derecho de manifestación, la jurisprudencia constitucional y convencional han impuesto a la autoridad gubernativa una observancia especialmente escrupulosa en la aplicación del principio de proporcionalidad al que se hacía referencia supra, como un criterio interpretativo a tener muy en cuenta respecto del uso que el Gobierno y el resto de poderes públicos puedan hacer de sus atribuciones especiales durante la vigencia el estado de alarma. 
Entre los criterios que dicha jurisprudencia ha establecido, y que son de relevancia para el objeto de este trabajo, cabe retener, por ejemplo, que el límite en la preservación del orden público se ha de basar en un temor fundado y razonable no en una mera sospecha- de riesgo para la integridad de personas y bienes (SSTC 101/1985, 68/2005, o STEDH Stankov c. Bulgaria, de 2 de octubre de 2001); la noción de lugar de tránsito público ha de interpretarse estrictamente, como sinónimo de espacio abierto a la generalidad de personas (STC 196/2002); el mero incumplimiento del requisito de la comunicación previa no justifica por sí solo la prohibición de la manifestación, ni menos aún el uso de la fuerza; las molestias para el tráfico han de entenderse como una carga inherente al derecho de reunión y manifestación siempre que, naturalmente, no alcancen el nivel de alteración del orden público (SSTC 265/2006 y 31/2007); además, siempre que no suponga una amenaza para el orden público, la autoridad gubernativa no puede vetar o condicionar el modo elegido para manifestarse por los promotores (STC 99/2004); asimismo, la vigencia de un periodo electoral no legitima a las Juntas Electorales para prohibir una manifestación, puesto que no responde al principio de proporcionalidad (STC 96/2010) [Díez-Picazo Giménez, 2018: 649].

A lo largo de la vigencia del estado de alarma, desde el 14 de marzo hasta la sexta y última prórroga que finalizó a las cero horas del 21 de junio de 2020, se produjeron convocatorias de diversas manifestaciones. En algunos casos la controversia sobre la desautorización o la competencia jurisdiccional para entender del asunto se residenciaron finalmente ante juzgados y tribunales.

Así, justo una semana después de ser decretado el estado de alarma, el 21 de abril, la Subdelegación del Gobierno en Pontevedra emitió una resolución que acordó la denegación de una manifestación convocada por la Central Unitaria de Trabajadores (CUT), a celebrar el $1^{\circ}$ de mayo. Este sindicato planteó un recurso contencioso-administrativo ante la sala competente del Tribunal Superior de Justicia de Galicia, que resolvió su desestimación. Además de rechazar que hubiese razones -como consideraba la parte recurrente- para promover ante el Tribunal Constitucional una cuestión de inconstitucionalidad contra el Real Decreto Ley $463 / 2020^{19}$, en el juicio de ponderación sobre los bienes jurídicos en presencia, en su sentencia de 28 de abril de 2020 el tribunal gallego acudió al argumento de la preservación de la salud pública (los enormes efectos provocados por la pandemia, la cantidad de fallecidos y afectados, la no contención de la propagación del virus, etc.) para interpretar que debía prevalecer frente al derecho de manifestación incluso excluyendo -como proponía el sindicato convocante- de realizar la manifestación con los participantes circulando en los coches.

19 Recuérdese que, de acuerdo con la mayoritaria opinión de la Sala 1aㅡ del Tribunal Constitucional, el decreto por el que se proclama el estado de alarma tiene valor de ley (ATC 7/2012, de 13 de enero). Esta resolución contó con el voto particular en contra formulado por el magistrado Luis I. Ortega Álvarez, al que se adhirieron los magistrados Javier Delgado Barrio y Pablo Pérez Tremps. 
El sindicato convocante recurrió en amparo ante el Tribunal Constitucional, que en una extensa resolución de su Sala Primera -ATC 40/2020, de 30 de abril- resolvió inadmitir a trámite, argumentando que, en el momento en el que se encontraba la situación sanitaria del país, resultaba prevalente asegurar el derecho a la garantía de la integridad física de las personas (art. 15) y la protección de la salud de las mismas (art. 43) ${ }^{20}$. Conviene subrayar que, en su ratio decidendi, el Tribunal precisó que en este caso lo que dilucidaba no era la garantía del orden público sino la preservación de los derechos citados.

Fue una decisión razonable. En efecto, si, por razones fundadas en la imperiosa necesidad de preservar la salud de las personas, el estado de alarma supone una limitación de la libre circulación de personas, la distancia física de las mismas, la salida a la calle controlada por franjas de edad, etc., y todo ello destinado también a evitar posibles rebrotes de la pandemia que pudiesen colapsar el sistema sanitario, la consecuencia es que, siempre en función de la situación sanitaria de cada territorio concreto, resulta razonable que, con la debida ponderación jurídica que exige la especificidad de cada caso, en el que concretamente dio lugar al recurso éste fuese desestimado, y la manifestación no autorizada por el TSJ de Galicia.

Con posterioridad, y a lo largo de la vigencia del estado de alarma, se produjeron diversas resoluciones de la jurisdicción ordinaria relativas al derecho de manifestación, consecuencia de recursos planteados contra decisiones prohibitivas de la autoridad gubernativa. En las que aquí se reseñan, el órgano judicial aplica la regla de la ponderación de los derechos y en algún caso también pone énfasis en el test de proporcionalidad aplicado a la decisión administrativa. Todas ellas resuelven a favor de la prevalencia del derecho de manifestación. En general, se tienen en cuenta las circunstancias de la evolución de la situación sanitaria y las garantías ofrecidas por los convocantes de la manifestación para preservar la salud. Sin embargo, en alguna se aprecia una errónea concepción de la relación entre la libertad de circulación y el derecho de manifestación.

Por ejemplo, es el caso de la sentencia de 29 de abril de 2020, emitida por la Sección $1^{\text {a }}$ de la Sala de lo Contencioso-Administrativo del Tribunal Superior de Justicia de Aragón, que, con ocasión de la aplicación de las medidas contempladas por el artículo 7 del Real Decreto 463/2020, establece una rígida y, por ello, difícil distinción conceptual entre la libertad de circulación y el derecho de reunión/manifestación. Lo argumenta de esta forma:

20 "Las razones que sustentan ambas son idénticas y buscan limitar el impacto que en la salud de los seres humanos, en su integridad física y en su derecho a la vida pueda tener la propagación de la COVID-19. En el estado actual de la investigación científica, cuyos auances son cambiantes con la evolución de los días, incluso de las horas, no es posible tener ninguna certeza sobre las formas de contagio, ni sobre el impacto real de la propagación del virus, así como no existen certezas científicas sobre las consecuencias a medio y largo plazo para la salud de las personas que se han visto afectadas en mayor o menor medida por este uirus. Ante esta incertidumbre tan acentuada y difícil de calibrar desde parámetros jurídicos que acostumbran a basarse en la seguridad jurídica que recoge el art. 9.3 de la Constitución, las medidas de distanciamiento social, confinamiento domiciliario y limitación extrema de los contactos y actividades grupales, son las únicas que se han adverado eficaces para limitar los efectos de una pandemia de dimensiones desconocidas hasta la fecha. Desconocidas y, desde luego, imprevisibles cuando el legislador articuló la declaración de los estados excepcionales en el año 1981" (FJ 4). 
[L]o que caracteriza y cualifica al derecho de manifestación, respecto de la libertad individual o deambulatoria, es que el necesario vehículo personal, la concentración de ciudadanos en un determinado lugar, opera "al servicio del intercambio y libre exposición de ideas, de defensa de intereses o de publicidad de problemas y reivindicaciones" (FJ 3).

Cierto, es así. El derecho de manifestación está concebido como efectivamente interpreta la jurisprudencia constitucional y así lo recoge el TSJ en su sentencia, un canal de expresión de ideas en defensa de intereses (entre otras, la STC 193/2011). Pero, para reunirse en el espacio público y manifestar una posición reivindicativa, previamente es preciso disponer de capacidad para circular por la vía pública y acudir a la manifestación. Resulta obvio. Ahora bien, por el contrario, si se afirma como lo hace el TSJ de Aragón, que estando vigente el estado de alarma “... cabrá la posibilidad de limitar los movimientos del ciudadano en mayor o menor medida, pero nunca para impedir el libre ejercicio del derecho de manifestación" (FJ 3), la distinción a la que se aventura la Sala del citado TSJ resulta del todo incoherente. Para manifestarse en la vía pública es preciso disponer antes de libertad de circulación. Por esta razón, esta distinción es muy rígida porque parte de un presupuesto erróneo, cual es el de entender ambos derechos fundamentales como una especie de compartimentos estancos cuando pueden estar íntimamente relacionados.

Ya avanzado el mes de mayo, con ocasión de una ligera desescalada en las medidas restrictivas y de control sanitario en la propagación del virus, las convocatorias de algunas manifestaciones fueron también desautorizadas por resoluciones de la autoridad gubernativa. Sin embargo, serían declaradas nulas por diversas sentencias. Este fue el caso de la Sentencia de la Sección $1^{\text {a }}$ de Sala del Tribunal Superior de Justicia de Castilla y León, con sede en Valladolid, de 21 de mayo de 2020. En aplicación del principio de proporcionalidad, el TSJ entendió que las garantías sanitarias ofrecidas por el partido político de extrema derecha VOX para llevar a cabo una manifestación mediante una caravana de vehículos eran suficientes. En una línea semejante se pronunció la Sección $3^{\text {a }}$ de la Sala de lo Contencioso-Administrativo del Tribunal Superior de Justicia de Cataluña, en su sentencia 1391/2020, de 22 de mayo, ante la comunicación de una manifestación convocada por la misma entidad política. O también, la sentencia emitida por la sección $10^{\text {a }}$ de la Sala de lo Contencioso-Administrativo del Tribunal Superior de Justicia de Madrid, de 21 de mayo de 2020, ante una comunicación de convocatoria de manifestación hecha por el Partido Comunista de los Pueblos de España (PCPE) en la que, no obstante, la anulación de la resolución administrativa de prohibición impugnada iba acompañada de una indicación del propio TSJ en el sentido de que la manifestación debía sujetarse a las condiciones establecidas en la sentencia. 


\section{EL DERECHO A LA PROTECCIÓN DE LOS DATOS PERSONALES}

Su presencia en el debate jurídico se ha producido a causa de la posibilidad -hasta ahora sin traducción normativa específica en una disposición- de que las autoridades sanitarias pudiesen establecer un control de los ciudadanos sometidos a una cuarentena en su domicilio a través de teléfono celular. La finalidad sería fiscalizar sus movimientos fuera del domicilio para evitar que la persona afectada por la pandemia y confinada en casa no vulnere esta situación y ponga en peligro la salud colectiva.

El derecho al habeas data o derecho a la autodeterminación informativa permite al ciudadano disponer de sus datos personales que circulan por la red e impedir que sean difundidos sin su previo consentimiento, salvo en los casos en que el Reglamento de la Unión Europea y la legislación nacional establezcan excepciones. Es evidente que la red de Internet y el teléfono celular, junto a otras redes sociales, constituyen un campo abonado al acceso a los datos del ciudadano sin que este tenga conocimiento de ello.

En todo caso, si una medida como la descrita fuese puesta en práctica, su legitimidad constitucional quedaría limitada a que el control de los datos del ciudadano concernido se refiriesen estrictamente a la protección de su salud y que, como consecuencia de la propagación de la pandemia, puedan afectar a la salud colectiva de la población. Con las debidas garantías de que los datos no puedan ser utilizados para otros fines. El Reglamento de la Unión Europea 2016/679, de 27 de abril de 2016, relativo a la protección de las personas físicas en lo que respecta al tratamiento de datos personales y a la libre circulación de estos datos y por el que se deroga la Directiva 95/46/CE (Reglamento general de protección de datos) establece dos principios esenciales que, en caso de que una norma nacional de este tenor fuese aprobada, deberían ser tenidos muy en cuenta: uno de ellos es el principio de minimización de datos, y el otro se refiere a la licitud de su tratamiento. De acuerdo con el primero, los datos susceptibles de ser obtenidos han de ser: "adecuados, pertinentes y limitados a lo necesario en relación con los fines para los que son tratados" [art. 5.1, c)]; y el segundo, para que la obtención de los datos sea lícita se prescribe que:

el tratamiento [sea]necesario para la satisfacción de intereses legítimos perseguidos por el responsable del tratamiento o por un tercero, siempre que sobre dichos intereses no prevalezcan los intereses o los derechos y libertades fundamentales del interesado que requieran la protección de datos personales, en particular cuando el interesado sea un niño. Lo dispuesto en la letra f) del párrafo primero no será de aplicación al tratamiento realizado por las autoridades públicas en el ejercicio de sus funciones [art. 6.1, f)].

Obviamente, entre las funciones de las autoridades públicas se encuentra la protección de la salud de las personas (art. $43 \mathrm{CE}$ ), en el marco de la distribución de competencias entre el Estado y las CC.AA. (art. 149.116a CE). 


\section{LAS REDES SOCIALES COMO SOPORTE DE LA LIBERTAD DE EXPRESIÓN Y DEL DERECHO A COMUNICAR Y RECIBIR INFORMACIÓN}

El impacto de la pandemia sobre los medios de comunicación y, entre ellos, el amplio espectro de las redes sociales ha sido notorio. El ejercicio de la libertad de expresión en estos tiempos traumáticos ha dado para todo. En efecto, algunos casos de actualidad confirman que el ejercicio de la libertad de expresión puede dar mucho de sí: desde las manifestaciones más brillantes del pensamiento humano, sobre todo cuando la razón como seña de identidad es el hilo conductor que las preside, hasta las más miserables de las que es capaz de emitir una persona, pasando por aquellas otras intrascendentes, tópicas o estúpidas de las que los humanos también pueden ser capaces.

Como criterio general, el Estado liberal democrático ha de dar cobertura a todas ellas, pues en ello consiste el derecho fundamental a la libertad de expresión. No es un derecho cuyo ejercicio obligue a un resultado concreto. En todo caso, será su entorno más próximo y, en su caso, el conjunto de la sociedad quien valore lo expresado.

La libertad de expresión es un pilar esencial de todo sistema que se precie democrático. Obviamente, quienes son titulares de la libertad de expresión son las personas pero no -por cierto- las instituciones representativas, que deben sujetarse a un escrupuloso deber de neutralidad en sus expresiones públicas. Su garantía es condición sine qua non para el ejercicio efectivo de otros derechos como la libertad ideológica. La condición de derechos fundamentales, con ser decisiva para la calidad democrática de la sociedad, no significa que sean absolutos. Salvo el derecho a no ser sometido a tortura o tratos inhumanos y degradantes, el resto están sujetos a límites.

Es un hecho contrastado que las redes sociales han facilitado las posibilidades de que la ciudadanía se exprese sobre los temas más diversos. Si objetivamente constituyen una excelente plataforma de expresión y participación, también son un campo abonado para auténticos despropósitos dialécticos y morales, cuando no expresión de patéticos momentos de presunta gloria individual.

Con la creación de una red difusa de usuarios de las redes sociales en constante comunicación los unos con los otros, se ha alterado la distribución de la comunicación que, hasta la aparición de las diversas plataformas de World Wide Web, quedaba bajo el control de los medios convencionales. La extensión de las redes ha hecho que en la actual sociedad de la comunicación importen menos los contenidos que atraer circunstancialmente la atención. El neologismo viral, atribuido a aquella información o aquellas expresiones que causan impacto y atraen la atención sobre un hecho o persona concreta, se ha convertido en un campo abonado para el uso irresponsable, cuando no lesivo, de los derechos fundamentales ex artículo 20 CE. En la crisis sanitaria provocada por la COVID-19 han abundado hechos de este tipo, con la difusión de noticias falsas, expresiones insultantes dirigidas a responsables políticos y profesionales sanitarios. 
La idea según la cual, y llegado el caso, la voluntad popular pueda prevalecer sobre la legalidad democrática vigente se ha instalado en determinados sectores del imaginario colectivo, a través de la emisión de mensajes de opinión e incluso de informaciones que ofrecen soluciones sencillas a problemas que son complejos (Mounk, 2018:18), como la determinación de las causas y los remedios para afrontar la pandemia que, por su propia naturaleza, se ha demostrado que son muy complejos. La aproximación populista al problema ha formado parte del comportamiento mostrado por una parte del personal político, comunicadores diversos, profesionales de la información y ciudadanos habituales de las redes sociales, que rechazan cualquier intermediación o condicionamiento formal a la voluntad del pueblo. Desde esta lógica de comportamiento, estos actores políticos han mostrado un absoluto menosprecio por el mandato constitucional de la veracidad informativa, cuyo requisito principal para gozar de protección jurídica es que haya sido obtenida con diligencia profesional.

La pandemia de la COVID-19 ha sido un buen banco de pruebas para verificar el uso que los diversos actores sociales han hecho tanto de la libertad de expresión [art. 20.1. a) CE] como del derecho a comunicar y recibir información veraz [art. 20.1 d) CE]. Circunstancia esta que obliga a recordar algunos criterios jurisprudenciales sobre qué es lo que protegen ambos derechos fundamentales.

Siguiendo la doctrina establecida por el Tribunal Europeo de Derechos Humanos, la jurisprudencia constitucional desde sus inicios ha interpretado que la libre expresión garantiza el derecho de crítica, y muy particularmente la crítica política, sin que ello legitime el insulto. Pero la mayor relevancia pública de la expresión, sea por su contenido o por la persona a la que se refiere, hace que la libertad crítica goce de un mayor grado de protección. Tal circunstancia hizo que, ya desde un lejano 7 de diciembre de 1976 (Caso Handyside), y de nuevo diez años después, el 8 de julio de 1986, el Tribunal de Estrasburgo sentase la interpretación sobre la libertad de expresión, consagrada en el Convenio de Roma sobre garantía de los derechos fundamentales, interpretando que "no se aplica solamente a las 'informaciones' o 'ideas' que se reciben favorablemente o se consideran inocuas o indiferentes, sino también a las que ofrecen, hieren o molestan. Así lo exigen el pluralismo, la tolerancia y la mentalidad amplia, sin los cuales no hay sociedad democrática" (Caso Lingens).

En los sistemas democráticos vigentes, el planteamiento de la libertad de expresión, cuando esta se sitúa en el terreno del exceso gratuito, tampoco ha de estar sujeta a la inmediata respuesta penal. Cierto, la libertad de expresión no es omnímoda. Pero límite a la expresión miserable habría uno e infranqueable, y es el que se fundamenta teniendo en cuenta la conocida doctrina del juez Holmes basada en la regla del clear and present danger test: la incitación directa a la violencia. Fuera de estos casos, es preferible que la sociedad conozca a sus miserables y extraiga las consecuencias. Aquellas expresiones odiosas o que puedan concitar desprecio pero 
carentes del elemento doloso dirigido a provocar una inmediata acción violenta no habrían de ser objeto de respuesta penal; sobre todo, teniendo en cuenta la ambigüedad de la que resulta depositario por ejemplo, el elemento objetivo del tipo en los delitos de odio del artículo 510 del Código Penal, y ello sin perjuicio de reconocer el esfuerzo interpretativo contenido en la Circular 7/2019, de 14 de mayo, de la Fiscalía General, sobre las pautas para interpretar los delitos de odio tipificados en el artículo 510 del Código Penal ${ }^{21}$.

Finalmente, en lo que concierne a la comunicación de información a través de las redes sociales, el hecho de que el soporte técnico de difusión sean estas, en cualquiera de sus múltiples modalidades de acceso generalizado, no exime a su autor de responsabilidad. Las reglas interpretativas que operan para la información en los medios convencionales han de ser también operativas cuando en la red se difunden noticias falsas. Esto es, algunos de los criterios hermenéuticos establecidos por la jurisprudencia constitucional no desaparecen y siguen estando vigentes cuando es la red el medio a través del cual se expresa el mensaje, aun cuando en ocasiones sean notorias las dificultades para determinar el titular responsable.

En consecuencia, y a modo de síntesis, también en la red será preciso: 1) Distinguir entre la libertad de expresión y el derecho a comunicar y recibir información veraz. En el primer caso, por la existencia de elementos valorativos; y en el segundo, por la relevancia de factores de naturaleza fáctica que integran el objeto de la información (entre otras, las SSTC 6/1988; 178/1993, 138/1996). 2) Será preciso tener en cuenta que el derecho a la información, según los casos, ocupa una posición similar a la que es propia de un primus inter pares respecto de los derechos de la personalidad: a) cuando la información verse sobre asuntos en los que por razón de su objeto sea relevante o resulte de interés general, o los hechos resulten noticiables; b) o bien cuando la información se refiera a personas que, en razón de su dimensión pública, por el cargo que ocupan, la función representativa que ejercen (personajes públicos) o la actividad profesional que habitualmente desarrollan (personajes de notoriedad pública), también resulten de interés público (SSTC 171/1990 y 134/1999). 3) El derecho de crítica a las instituciones públicas, y a aquellos que temporalmente las representan, es una lógica consecuencia de la libertad ideológica y el pluralismo político (STC 20/1990, o la ya citada STEDH de 8 de julio de 1986, Caso Lingens c. Austria). 4) La veracidad en la información es un límite constitucional que ha de ser entendido en términos relativos y no absolutos; en consecuencia, gozará de protección constitucional aquella información que haya sido elaborada y difundida con diligencia y buena fe profesional, es decir, con escrupuloso respeto a las normas deontológicas de la profesión periodística, incluso en los casos en los que hayan podido incurrir en 
errores (STC 6/ 1988); y si se trata de un particular como sujeto activo de la información, este no quedará exento de responsabilidad en caso de falsedad. 5) La veracidad informativa no siempre exculpa de responsabilidad: la veracidad no legitima la injuria. (SSTC 105/1990, 171/1990 y 172/1990). 6) La relevancia jurídica del mandato constitucional de la veracidad informativa no es la misma cuando se enfrenta al derecho al honor que cuando afecta al derecho a la intimidad. La veracidad opera como causa legitimadora de las intromisiones en el derecho al honor, mientras que su relevancia puede ser distinta si el bien jurídico afectado concierne al derecho a la intimidad. En este caso, la intromisión será legítima solo si se justifica en función del interés público que trascienda de la información difundida (STC 171/1990). ^

\section{BIBLIOGRAFÍA}

Albertí Rovira, E. (1985). La ejecución estatal forzosa. En E. Aja, et al. El sistema jurídico de las Comunidades Autónomas, (pp. 471-746). Madrid: Tecnos.

Áluarez Áluarez, L. (2016). La coerción estatal del artículo 155 CE en la estructura del Estado autonómico. Teoría y Realidad Constitucional, (38), 277-304.

Áluarez García, V. (2020). El coronauirus (COVID-19): respuestas jurídicas frente a una situación de emergencia sanitaria. El Cronista del Estado social y democrático de Derecho, (86-87), 5-19.

Aragón Reyes, M. (11 de abril de 2020). Hay que tomarse la Constitución en serio. El País.

Recuperado de https://elpais.com/elpais/2020/04/09/ opinion/1586420090_736317.html

Barcelona Llop, J. (1995). Orden Público (Do․ Administrativo). En Enciclopedia Jurídica Básica, vol. III (pp. 560-4635). Madrid: Civitas.
Barnés Vazquez, J. (14 de agosto de 2020). Un falso dilema. El País. Recuperado de https://elpais.com/ opinion/2020-08-13/un-falso-dilema.html

Bernal Pulido, C. (2007). El principio de proporcionalidad y los derechos fundamentales. $3 \stackrel{\text { a }}{ }$ ed. Madrid : Centro de Estudios Políticos y Constitucionales.

Carrillo, M. (17 mayo 2020). Los derechos en tiempo de pandemia. Al revés y al derecho [Blog]. Recuperado de http://blogs.infolibre.es/ alrevesyalderecho/?p=5800

Carrillo, M. (2020). Impact constitutionnel sur l'État de droit des mesures adoptées en Espagne. Démocratie, État de droit et droits fondamentaux face à la pandémie de Covid-19: perspectives croisées [Conférence virtuelle 30 auril 2020].

Recuperado de https://dice.uniu-amu.fr/sites/dice. uniu-amu.fr/files/public/m.carrillo_impact_constitutionnel_sur_letat_de_droit_des_mesures_adoptees_en_espagne-1.pdf 
Constitución española. En Trabajos Parlamentarios. (1980). Vol. II (pp. 1356-1361). Madrid: Cortes Generales.

Cruz Villalón, P. (1984). Estados excepcionales y suspensión de garantías. Madrid: Tecnos.

Cruz Villalón, P. (17 de abril de 2020). La Constitución bajo el estado de alarma. El País, p. 9. Recuperado de https://elpais.com/elpais/2020/04/16/ opinion/1587025782_733659.html

De la Quadra-Salcedo, T. (17 de marzo de 2020). (I) Estado de alarma y lealtad. El País, p. 9. Recuperado de https://elpais.com/elpais/2020/03/16/ opinion/1584378059_121764.html

De la Quadra-Salcedo, T. (8 de abril de 2020). (II) Límite y restricción, no suspensión. El País, p. 9. Recuperado de https://elpais.com/elpais/2020/04/07/ opinion/1586245220_558731.html

De la Quadra-Salcedo, T. (28 de abril de 2020). (III) La auersión europea al estado de excepción. El País, p. 9. Recuperado de https://elpais.com/el pais/2020/04/27/opinion/1587997245_501599 html

Díez-Picazo Giménez, L. Mạ (2018). Artículo 21. En M. Rodríguez-Piñero y Bravo Ferrer y M. E. Casas Baamonde (Dirs.). Comentarios a la Constitución española, tomo I (pp. 645-652). Madrid: BOE/Fundación Wolters Kluwer.

García de Enterría, E. (1983). La ejecución autonómica de la legislación del Estado. Madrid: Civitas.

García Sáez, J. A. (3 abril 2020). Garantizar los derechos humanos durante estado de alarma. Al revés y al derecho [Blog]. Recuperado de

http://blogs.infolibre.es/

alrevesyalderecho/?p=5755
García Torres, J. (2019). El artículo 155 paso a paso. En El artículo 155 de la Constitución. Asociación de Letrados del Tribunal Constitucional (pp. 105-172). Madrid : Tribunal Constitucional : Centro de Estudios Políticos y Constitucionales.

Gil-Robles y Gil Delgado, J. Ma y Gil-Robles Casanueva, L. (1999). Artículo 155. El control extraordinario de las Comunidades Autónomas. En O. Alzaga Villaamil, (Dir.) Comentarios a la Constitución española de 1978. Madrid: Edersa.

Hottelier, M. (2020). Démocratie, État de droit et droits fondamentaux face à la pandémie de Covid-19. Suisse. Démocratie, État de droit et droits fondamentaux face à la pandémie de Covid-19: perspectives croisées [Conférence virtuelle 30 auril 2020]. Recuperado de https://dice.uniu-amu. $\mathrm{fr} /$ sites/dice.uniu-amu.fr/files/public/m. hotteliersuisse.pdf

Ley orgánica de los estados de alarma, excepción y sitio: trabajos parlamentarios (1984). López Garrido, D. (Dir). Madrid: Cortes Generales.

Losada González, H. (2018). Articulo 19. En M. Rodríguez-Piñero y Brauo Ferrer y M. E. Casas Baamonde, (Dirs.) Comentarios a la Constitución española, tomo I (pp. 567-579). Madrid: BOE/ Fundación Wolters Kluwer.

Luciani, M. (2020). Il sistema delle fonti del diritto alla prova dell'emergenza. Rivista della Associazione Italiana del Constituzionalisti, (2), 109-141.

Milella, L. (8 marzo 2020). Coronauirus, Azzariti: "Le misure sono costituzionali a patto che siano a tempo determinato". La Repubblica. Recuperado de https://www.repubblica.it/politica/2020/03/08/ news/coronauirus_azzariti_le_misure_sono_ costituzional_a_patto_che_siano_a_tempo_determinato_-250680089/ 
Mounk, Y. (2018). Le peuble contra la démocratie. Éditions de l'Observatoire. (Versión en francés del original : The people u. Democracy. Why our freedon is in danger \& how to save it. Harvard University Press. Hay traducción al castellano en: El pueblo contra la democracia. Por qué nuestra libertad está en peligro y como saluarla. Paidós, Barcelona 2018).

Muñoz Machado, S. (27 de abril de 2020). La Constitución, la peste y la economía. El País, p. 11. Recuperado de https://elpais.com/elpais/2020/04/26/ opinion/1587892880_109743.html

Pérez Serrano, N. (1984). Tratado de Derecho Político. Madrid: Ciuitas.

Presno Linera, M. A. (26 marzo 2020). Por qué se decreta un estado de alarma y no de excepción por el coronavirus. The Conversation. Recuperado de https://theconversation.com/por-que-se-decretaun-estado-de-alarma-y-no-de-excepcion-por-elcoronavirus-134806
Urías, J. (14 abril 2020). Estado de alarma y limitación de derechos: ni excepción, ni suspensión". Al revés y al derecho [Blog]. Recuperado de http://blogs.infolibre.es/alrevesyalderecho/?p=5774

Velasco Caballero, F. (2020). Estado de alarma y distribución territorial del poder. El Cronista del Estado social y democrático de Derecho, (8687), 76-85.

Verdussen, M. (2020). Démocratie, État de droit et droits fondamentaux face à la pandémie de Covid-19. La situation en Belgique. Démocratie, État de droit et droits fondamentaux face à la pandémie de Covid-19: perspectives croisées [Conférence virtuelle 30 auril 2020]. Recuperado de https:// dice.uniu-amu.fr/sites/dice.uniu-amu.fr/files/ public/m._verdussen-note_de_travail_ndeg_115_auril_2020.pdf 